\title{
Aspects for cultivating creative literacy through play: an analysis on primary literature review and preliminary laboratorial work
}

\author{
José Raimundo, Pedro Cardoso, Miguel
}

Carvalhais \& António Coelho

\begin{abstract}
:
This article inspects theory emerging from literature review and laboratory work on games for cultivating creative literacy. Whether games can or cannot instil or alienate one's creativity is debatable. On one hand, they can be risk- and stress-free exploring grounds for people to interact in ways without parallel; on another, they can disengage players from the real world. Nevertheless, they have the potential to be turned into tools for thinking, for learning and for articulating knowledge between individuals. With that into consideration, we pinpointed two main groups that branch into four major categories: Behaviours - comprised of Attitudes and Competencies - and Conditions - comprised of Procedures and Resources - which we are structuring into a framework from which we draw hypotheses that undergo validation through play-testing sessions, in order to improve the framework.
\end{abstract}

Keywords:

creative literacy; games; play; game design. 


\title{
Aspectos para o cultivo da Literacia Criativa através do jogo: Uma análise sobre a revisão da literatura e trabalho laboratorial preliminar
}

\begin{abstract}
Resumo: Este artigo inspeciona teoria emergente da revisão de literatura e de trabalho de laboratório em jogos para o cultivo da literacia criativa. É discutível se os jogos podem ou não instilar ou alienar a criatividade de alguém. Por um lado, podem ser um campo de exploração livre de riscos e stress para as pessoas interagirem de formas sem precedentes; por outro, podem alienar jogadores do mundo real. No entanto, eles têm o potencial de serem transformados em ferramentas de pensamento, de aprendizagem e para articular conhecimentos entre indivíduos. Com isso em consideração, identificamos dois grandes grupos que se ramificam em quatro categorias principais: Comportamentos - compostos por Atitudes e Competências - e Condições - compostos por Procedimentos e Recursos - que estamos a estruturar numa framework a partir da qual extraímos hipóteses que são validadas através de sessões de teste de jogo, a fim de a melhorar.
\end{abstract}

Palavras-chave: literacia criativa; jogos; jogar; design.

\section{Aspects pour cultiver la littératie créative avec des jeux: Une analyse de la revue de littérature et du travail de laboratoire préliminaire}

Résumé: Cet article examine la théorie issue de la revue de la littérature et du travail de laboratoire sur des jeux pour développer la littératie créative. Que les jeux puissent ou non inculquer ou aliéner la créativité est discutable. D'un côté, ils peuvent constituer un terrain d'exploration sans risque ni stress pour que les gens puissent interagir de manière sans parallèle; sur un autre, ils peuvent désengager les joueurs du monde réel. Néanmoins, ils peuvent potentiellement être transformés en outils de réflexion, d'apprentissage et d'articulation des connaissances entre les individus. Cela étant dit, nous avons identifié deux groupes principaux qui se divisent en quatre catégories principales: Comportements - comprenant des attitudes et des compétences - et des conditions - comprenant des procédures et des ressources - que nous structurons dans un cadre à partir duquel nous tirons des hypothèses validées sessions de test de jeu, afin d'améliorer le cadre.

Mots clés: littératie créative; jeux; jouer; design.

\section{Aspectos para cultivar la alfabetización creativa a través del juego: Un análisis sobre la revisión de literatura y el trabajo de laboratorio preliminar}

Resumen: Este artículo inspecciona la teoría que emerge de la revisión de literatura y el trabajo de laboratorio en juegos para cultivar la alfabetización creativa. Es discutible si los juegos pueden o no inculcar o alienar la creatividad de uno. Por un lado, pueden ser campos de exploración libres de riesgo y estrés para que las personas interactúen de manera sin paralelo; Por otro lado, pueden desconectar a los jugadores del mundo real. Sin embargo, tienen el potencial de convertirse en herramientas para pensar, para aprender y para articular el conocimiento entre individuos. Teniendo esto en cuenta, identificamos dos grupos principales que se dividen en cuatro categorías principales: Comportamientos, compuestos por actitudes y competencias, y condiciones, compuestos por procedimientos y recursos, que estamos estructurando en un marco a partir del cual extraemos hipótesis que se validan a través de sesiones de prueba de juego, para mejorar el marco.

Palabras clave: alfabetización creativa; juegos; jugar; diseño. 


\section{Introduction}

In general terms, one can define being literate as the state of being educated or cultured, along with the ability to understand, to exchange and to create meanings. With this into consideration, one can define Creative Literacy as the quality of being educated with knowledge, competencies, sensitivity and capacity to create. In educational contexts creative literacy, according to Woods (2007, p.65), is "literacy that brings about personal change, empowers and enriches".

Games can be valuable in this context, as they are able to incorporate beliefs in their systems and allowing players to think and to interact in alternative ways (Flanagan, 2009). And in the same way games can be good instruments for teaching (Gee, 2004), we believe they can also be more than adequate instruments for promoting creative literacy. While some games are built with challenges to be solved in a predetermined way, others provide more freedom, allowing players to look for alternative solutions and diverse ways on how to play. Whichever the case, games often demand creative solutions from players, sometimes in ways pretty much unforeseen by their game designers. So, while games with challenges aimed at single solution can promote convergent thinking, those that allow more freedom in play can promote divergent thinking - which are both key-competencies for problem-solving and to be creative.

It is in this context that the research questions for this project reside: How can games be used to cultivate creative literacy? And how can they be designed?

\section{Towards a framework}

We focused this preliminary research on diverse fields of knowledge - Creativity Studies, Game Studies, Game Design, Theory in Education, Arts, Science, Philosophy of Literature and Technology, Psychology, Neuroscience, and Evolutionary Studies - in search of what we saw that could be useful for stimulating creative acts. And so, informed by this literature review, we were able to identify several key-aspects we believe to be relevant for assessing and building one's creative literacy (which we detail in the upcoming sections). We then categorized those into groups that relate with several dimensions we believe to be key, which then allowed us to structure a preliminary version of a framework that enabled us to draw hypotheses that take shape as game prototypes, which we are currently testing.

With that in mind, we were able to organise the current version of the framework in two major categories: Behaviours and Conditions. Behaviours can be defined as the way a person or a group of people act or conduct themselves. In this framework, these emerge from the interplay between Attitudes - which are ways of thinking or feeling about something, influencing how one acts - and Competencies - which are skills or abilities that allow a person to execute certain actions. 
On the other hand, Conditions consist of an ecology of factors that affect the way one Behaves. They are often contextual, and they derive from one's own circumstances or from a particular devised set-up. In this framework, Conditions are composed of Resources - which are the available supplies or means one resorts to be able to act - and Procedures - which are the methods of operation, ways of doing or acting.

\section{BEHAVIOURS}

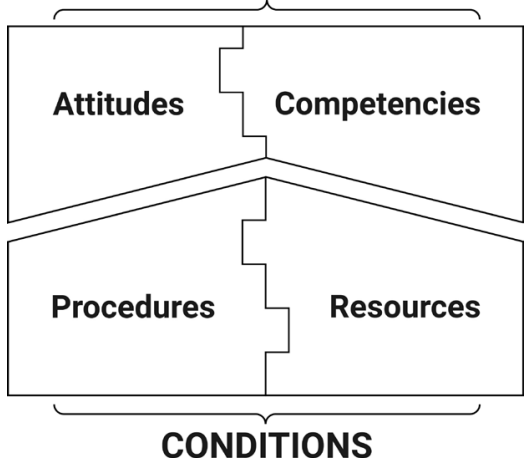

Figure 1. Schematic of the framework's components and how they relate with each other.

Table 1

Key-aspects organized by categories.

\begin{tabular}{|c|c|c|c|}
\hline Attitudes & Competencies & Procedures & Resources \\
\hline $\begin{array}{l}\text { 1. Risk-taking } \\
\text { 2. } \text { Communicative } \\
\text { 3. Confident } \\
\text { 4. Collaborative } \\
\text { 5. Inquisitive } \\
\text { 6. Attentive } \\
\text { 7. Playful } \\
\text { 8. Resilient } \\
\text { 9. Intuitive } \\
\text { 10. Subversive }\end{array}$ & $\begin{array}{l}\text { 1. Self-adaptation } \\
\text { 2. Empathetic thinking } \\
\text { 3. Parallel and Lateral } \\
\text { Thinking } \\
\text { 4. Analogical and } \\
\text { Metaphorical thinking } \\
\text { 5. Divergent thinking } \\
\text { 6. Convergent thinking }\end{array}$ & $\begin{array}{l}\text { 1. Destructive creativity } \\
\text { 2. Chance and Serendipity } \\
\text { 3. Iteration } \\
\text { 4. Repurposing } \\
\text { 5. Open-ended inquiry } \\
\text { 6. Peer talking } \\
\text { 7. Synergizing }\end{array}$ & $\begin{array}{l}\text { 1. Communal space } \\
\text { 2. Computational power } \\
\text { 3. Collective knowledge } \\
\text { 4. Prototypes } \\
\text { 5. Representations } \\
\text { 6. Memory }\end{array}$ \\
\hline
\end{tabular}

\section{List of Attitudes}

\subsection{Risk-taking}

A risk-taking attitude is the disposition of a person to take chances charged with responsibility for achieving specific goals. Risk-taking can help people escape from cultural conventions that often restrain their capacity to think creatively, and allow them to pave a path marked by openness and originality, guided by the question "why not?" (Hunter, 2012, p. 122). 


\subsection{Communicative}

Being communicative is to be willing to talk or to exchange information with others. In creative collaborative work, it is crucial for establishing connections with others and for managing such network. It is also key for reporting results to a wider audience in a comprehensive way.

\subsection{Confident}

Being confident is the state of being conscious of one's own competencies or circumstances and of relying on them. Being confident helps in ensuring that one's contributions to generate creative results are worthy of pursuit, increasing the chances to impress others and to stand one's ground.

\subsection{Collaborative}

Being collaborative is seen here as wanting to play a part in an activity with shared goals. Despite the fact that creativity can be seen as an individual phenomenon, innovation is likely to stem from a collaborative practice that benefits from multidisciplinary knowledge (Hunter, 2012).

\subsection{Inquisitive}

Being inquisitive is to tend to ask questions, to examine and to investigate driven by the curiosity to learn. Creators are naturally curious, and inclined to be attentive and open to their surroundings, since that can help them understand the innerworks of phenomena in the world (Melo, 2018). Being inquisitive can inspire creative acts and stimulate students to develop competencies, in the terms of Smilan (2016, p. 176), to "analyse, integrate, conceptualize, and [re]create", which are key-skills for a creative economy. In sum, this is a powerful attitude for fine-tuning results and enticing novelty by merely asking: what if...?

\subsection{Attentive}

To be attentive is to be a good listener and a good observer of ourselves, of others and of our surroundings. Moreover, to listen: a) helps make the most of one team's skills in a supportive work environment; b) allows one to understand an audience and client desires; c) allows one to know what is wrong with what we are creating; d) helps to know oneself, and therefore to master one's own creativity (Schell, 2008).

\section{7 Playful}

Being playful is an attitude that rises and exists through play. Play is an activity stressed between two opposing forces - creation and destruction - through which we perceive the world and ourselves. The act of playing is about thinking, manipulating and 
transforming rules in countless ways: contextual, fun, serious, hurtful, among others. Play liberates us from moral conventions so we can express ourselves on countless subjects and ways, while keeping us being aware of the importance of such conventions (Sicart, 2013).

\subsection{Resilient}

Resilience consists in knowing how to effectively deal with people and/or adverse circumstances and regulating one's emotions to achieve particular goals. Resilience is important here because it allows one to endure difficult situations and to discover creative possibilities to address them. According to Saturnino de la Torre (2005), resilient or paradoxical creativity is "transformative potential for self-realization, underlying in the states of need", anchored in "mistakes, casualties, adversities and limit situations" (translated from Ribeiro, 2018, p. 125), i.e. the creative potential emerges in dramatic circumstances.

\subsection{Intuitive}

Being intuitive is having the faculty of instantly knowing something or of being convinced of knowing, while being unable to provide evidence or a reasonable explanation to why. Intuition is also a synonym of insight, something important here as it is about having the competence to address complex open problems that cannot be solved through logic, math or deductive reasoning (Kounios, 2015, cited in Ribeiro, 2018, pp. 245-246).

\subsection{Subversive}

Being subversive is to compromise the dominance of established institutions, systems or norms. Carnivals are good examples of this subversive behaviour. According to Siccart (2014), they allow "[t]temporarily dismissing the oppressive forces of the establishment" and "[m]anaging the careful relations between creation and destruction" (p. 10), allowing people the freedom to express themselves in ways apart from their ordinary life. Furthermore, by abandoning social conventions, one can access alternative ways of reasoning or adopt other cultures with unfamiliar values or systems.

\section{List of Competencies}

\subsection{Self-adaptation}

Self-adaptation is the response to change in accordance to one's surroundings, to new or non-familiar conditions or contexts. Self-adaptation can be read as a common brain activity that transforms one's former cerebral structures into new ones to tackle particular issues (Eagleman, 2011). Self-adaptation is then a competence that allows 
people to transform themselves and their resources to address their needs creatively. As Eagleman (2011, p.73) puts it "In the logic of the brain, if you don't have the right tool for the job, create it".

\subsection{Empathetic thinking}

Empathy is commonly understood as the ability to get a sense of others' emotional states. One can also practice empathetic thinking with an object in order to better understand it, developing mental models. For example, one is able to grasp how a computational artifact functions by relating empathically with it, creating a Theory of the System, which is a mental formulation of one's understanding of how said system works, which improves by the confirmation or denial of its hypotheses in "a gradual process of creating meaning" (Carvalhais \& Cardoso, 2010, p. 224).

\subsection{Parallel and Lateral Thinking}

Traditional thinking uses solid logic, hermetic judgment and definitions to limit the perception of the world in an attempt to screen for new things. Conversely, lateral thinking is about making sense of things and give rise to new insights through specific techniques, like the provocations incited by the De Bono's (1995, p. 270) "Six Hats Method". Parallel thinking embraces a lack of consistency and contradiction to come up with new ways to design and build original things, or in De Bono's terms (1995, p. ix), "Parallel Thinking is concerned with design and creation."

\subsection{Analogical and Metaphorical thinking}

Metaphors and analogies are figures of speech in which one thing is used to represent something else. They are a way to relate or to compare things that may be apparently unrelated. For example, metaphorical thinking is key for creative thinking in the sciences and in the arts as they allow one to look for ways to relate unfamiliar things with those we already understand (Geary, 2011, pp. 12-13).

\subsection{Divergent thinking}

This is a form of thinking focused on seeking novelty and originality by exploring multiple alternative solutions for a particular problem or subject. Based on Guilford's work, Ribeiro says that divergent thinking is characterized by "[f]luidity, flexibility, originality, sensitivity to problems and competencies to deal with complexity" (as cited and translated from Ribeiro, 2018, p. 56).

\subsection{Convergent thinking}

According to Guilford (1950), this is the common mode of thinking when one looks for the right or the best solution among many possibilities when facing a problem (as 
cited by Ribeiro, 2018). It is useful to filter the many possibilities generated from divergent thinking. It is efficient in short runs, but it can come at the cost of rigidifying creativity in the long run, as happens with many organizations that tend to restrict their options in favour of focusing on a single one (Brown \& Wyatt, 2010).

\section{List of Procedures}

\subsection{Destructive creativity}

Destructive creativity is defined by Bauman (2006, p. 28) as " 'clearing the site' in the name of a 'new and improved' design; of 'dismantling', 'cutting out', 'phasing out', 'merging' or 'downsizing'", with the intent of increasing the capacity to do more of the same in the future, for competitive and production purposes. In this framework, we see destructive creativity as an opportunity to clear or to transform old ways of doing in order to enable the development of new designs, instead of following the same familiar paths.

\subsection{Chance and Serendipity}

Serendipity is a process of unexpected discovery of useful or original information through a combination of different levels of reasoning and chance. By intentionally using serendipity one may expect to give rise to creative value emerging from the unpredictable nature of serendipity itself (Melo, 2018).

\subsection{Iteration}

Iteration is a process where an action or series of actions that are repeated again and again in order to improve something. By its nature, iteration is a very useful process in the refinement and transformation of an idea, a concept, a prototype or even an already existing product.

\section{4 Repurposing}

Repurposing is an operation in which certain changes are applied to an idea, artefact or product in order for it to assume a new role or function. Often, new ideas, artefacts and products are built by exploiting the systems of their existing counterparts. Such is the case of SOD (1999), an abstract game created by JODI, by exploiting the game system of Wolfenstein $3 D$ (1992).

\subsection{Open-ended inquiry}

An "open-ended" mode of inquiry helps generating solutions for diverse problems (Pun, 2009, p. 100), as according to Brown \& Wyatt (2010, p. 34) by "[t]aking one provocative question at a time, the group may generate hundreds of ideas ranging from 
the absurd to the obvious." By stimulating open-ended inquiry, thinking is unrestrained, which can lead to original and novel ideas.

\subsection{Peer talking}

Peer talking is an activity where individuals belonging to proximal disciplinary areas engage in debate for exchanging ideas, to get inspired or to receive criticism. An informal and collaborative environment amongst participants is key for insightful ideas that lead to creative work. Promoting the exchange of different perspectives can help participants assist each other, something emotionally enriching and with great potential for refining artistic work (Bryant, 2010).

\subsection{Synergizing}

Synergizing is seen here as a way to expand one's creative competencies beyond one man's reach, by harmonizing working efforts between distinct participants, and being receptive to their criticism and contributions. According to Vygotsky (2004), reaching for "collective creativity" can only be done by aggregating and taking advantage of seemingly insignificant drops of anonymous creative contributions.

\section{List of Resources}

\subsection{Communal space}

Communal spaces are places shared by diverse people independently or collaboratively pursuing particular activities. They are spaces mainly about establishing communities and can be somewhat long lasting - such as co-working spaces for start-ups companies, a classroom or a laboratory -, or can be quite ephemeral and transitory such as the space used for a collaborative workshop or hackathon. What is relevant in these spaces is that the communities they form are key for creativity to emerge because their members' diversity may alert the team of stagnation and can promote an environment where members can inspire or influence one another and start new projects. In the terms of Clifton and Crick (2016, p. 24), "These perspectives address the importance of localized diversity for knowledge sharing and co-creation.".

\subsection{Computational power}

Computational power is the capacity to determine meanings or answers through mathematical operations, which can be done by people or machines. It helps in learning subjects in non-standard educational way, which is relevant since educational standards can limit learning to the discovery of definitive answers because the proposed exercises only permit uncovering known propositions (Papert, 1993). For example, significant scientific discoveries have been made in Foldit (2008) because it's gameplay is 
focused on making players manipulate protein structures and having their results sent back to the game's server for analysis.

\subsection{Collective knowledge}

Collective knowledge is the scope of information or understanding built and shared by a number of people. Collective knowledge is useful here since creative solutions are easier to attain through the combination of the efforts and knowledge of several people that care for the same problems and are able to pitch in (Shirky, 2010).

\section{4 Prototypes}

A prototype is an early materialization of a product for users to evaluate on intuitiveness, usability, malfunction and aesthetics. Prototypes are useful for cultivating creative literacy as they serve to test concepts and ideas, bridging the expectations of their creators with the requirements of their end users, even if the users are the creators themselves.

\subsection{Representations}

A representation is the way a person or something is portrayed or described, e.g.: a sign, a picture, a symbol, a model, etc.. According to Damásio (Fronteiras do Pensamento e Instituto CPFL Cultura, 2013) "[i]mages are representations. It is the capacity of recovering images, and the possibility to manipulate images, that are the main source of creative execution" (23:06). For example, drawing is a primordial way to visually convey designs in a descriptive and comprehensive way (Cross, 2008), and usually the designers resort to drawing to help them design (Cross, 2008).

\subsection{Memory}

Memory is the capacity to store, replicate or recall things learned throughout one's experience. According to Damásio (Fronteiras do Pensamento e Instituto CPFL, 2013), "[m]emory is absolutely indispensable, and a memory of images is absolutely indispensable for creativity to exist." (20:41). Memories can be considered as positive or negative stimuli and can, therefore, influence decisions in one's creative process.

\section{Method and Preliminary Laboratorial Work}

Prototypes are being developed by exploring one or a few key-aspects of each major category of the framework. In order to do so, we aim for specific Behaviours we want players to experience (Attitudes and Competencies), and then we work on the gameplay to provide certain Conditions (Procedures and Resources) to see if those behaviours occur along the game. Observing how such game prototypes are played 
and comparing what we intended players to experience with their actual reactions and feedback allows us to confirm or deny the application of the key-aspects we integrated in the prototype's gameplay, as well as their relevance in the framework.

The framework will evolve depending on these confirmations of the hypotheses, and depending on the case at hand, these hypotheses may either suffer an iterative convergent process focused on improvement or a generative exploratory divergent process focused on creating multiple variations of a given game. With this into consideration, we present next some prototypes developed by us in the course of this research: GAMESTROK!, Creative Speculative Infrastructure, Subverted Communication, Decision Leap, and Gas Crisis.

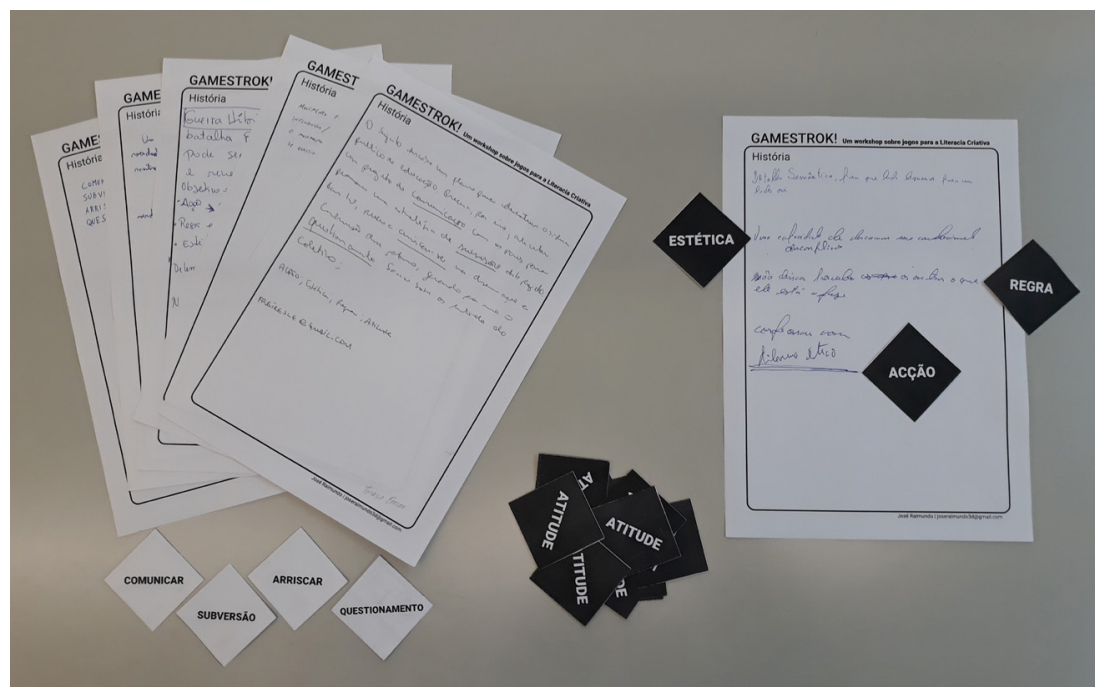

Figure 2. GAMESTROK! is a creative activity to develop game components.

GAMESTROK! is an activity where participants are invited to collaboratively develop a story that can inspire ideas for games. Participants adopt a collaborative Attitude for negotiating key-aspects drawn from an Attitude card deck and use collective knowledge (Resources) for interpreting these and to develop the story collectively. Upon the story completion, they try to identify game components through divergent and convergent thinking (Competencies), and then screen and negotiate them through peertalking (Procedures). 


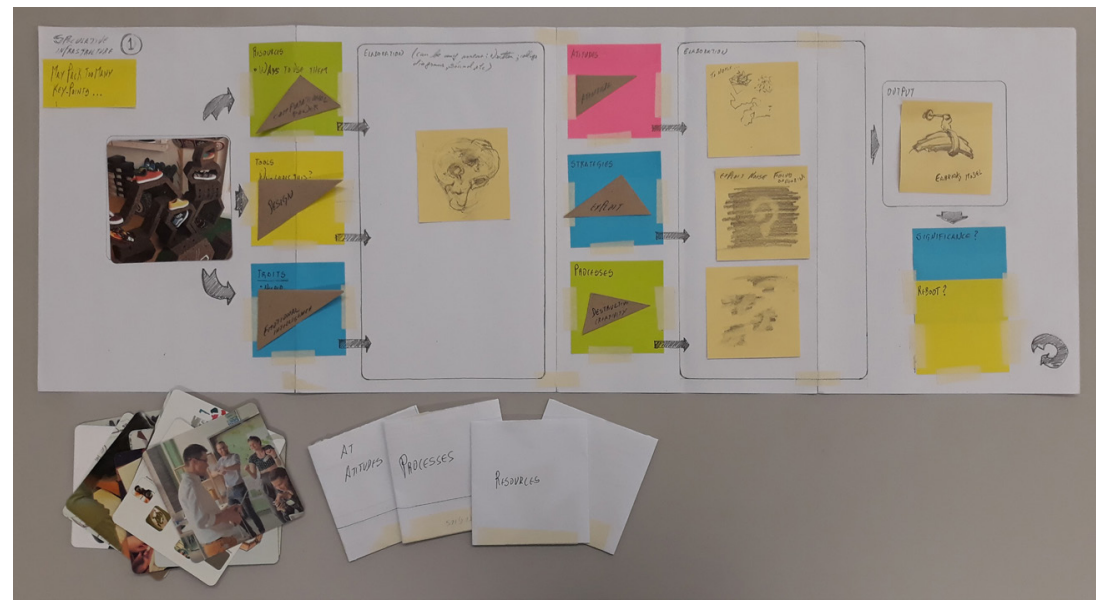

Figure 3. Creative Speculative Infrastructure is a prototype for generating ideas.

Creative Speculative Infrastructure guides the discovery of new ideas through inquisitive Attitudes. This is accomplished by drawing cards with key-aspects from decks with Attitudes, Competencies, Procedures and Resources, to influence players' creations.

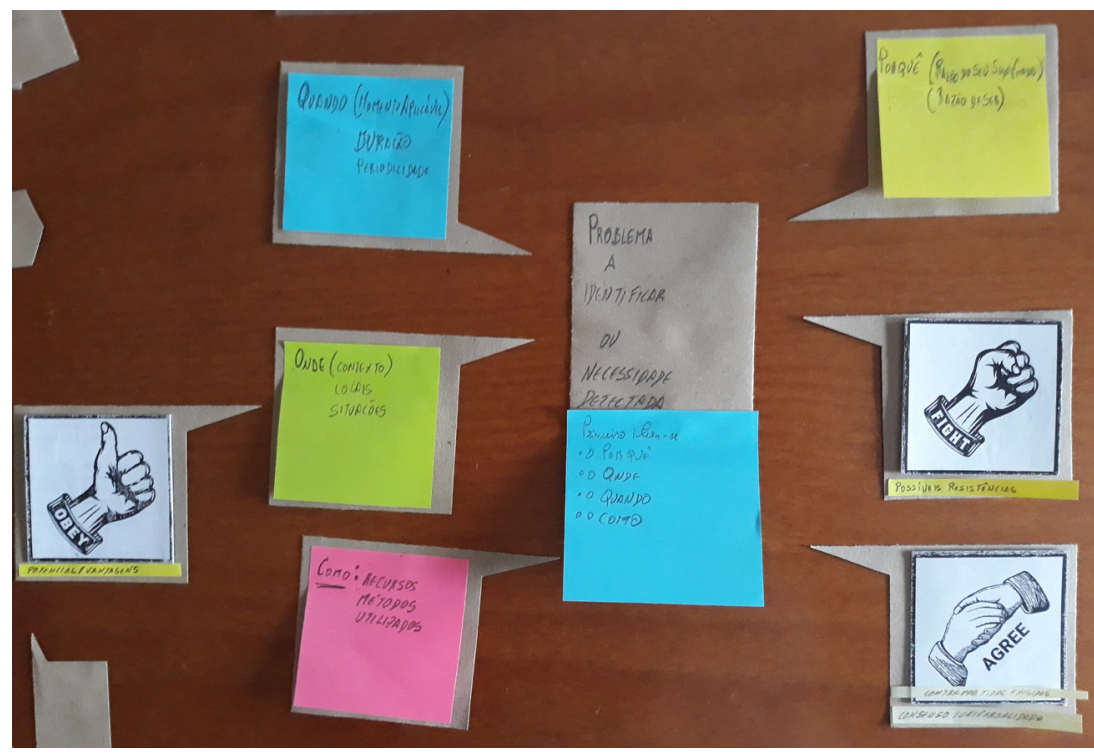

Figure 4. IdeaFocus is a prototype aimed to guide ideation sessions for potential Designs. 
IdeaFocus is a collaborative game for ideating things through inquisitive Attitudes. It uses divergent and convergent thinking (Competencies) and successive open-ended inquiry (Procedures) to reach for viable results. The game uses communal spaces (Resources) to stimulate players to conceive artefacts or solutions in a cohorted, proximal way.



Figure 5. Subverted Communication is a prototype aimed at ideation through subversion.

Subverted Communication is aimed at leading players towards subversive and communicative Attitudes so they can encounter new meanings and ideas, and as well explaining them. These new meanings and ideas become possible through associations that emerge from analogical and metaphorical thinking (Competencies), as well as by resorting to memory and representations (Resources). Such representations are negotiated through peer talking and are transformed through destructive creativity (Procedures). 




Figure 6. Decision Leap is a game for creating collective shapes.

Decision Leap is a multiplayer turn-based game aimed at creating shapes collaboratively and explaining how they came to be. Players adopt playful Attitudes to build the shapes, while resorting to representations and memory Resources. The explanations for how the collective shape evolve requires analogical and metaphorical thinking Competencies, while the players actions are influenced by Serendipity inductive Procedures, in the shape of card modifiers and dice rolls.

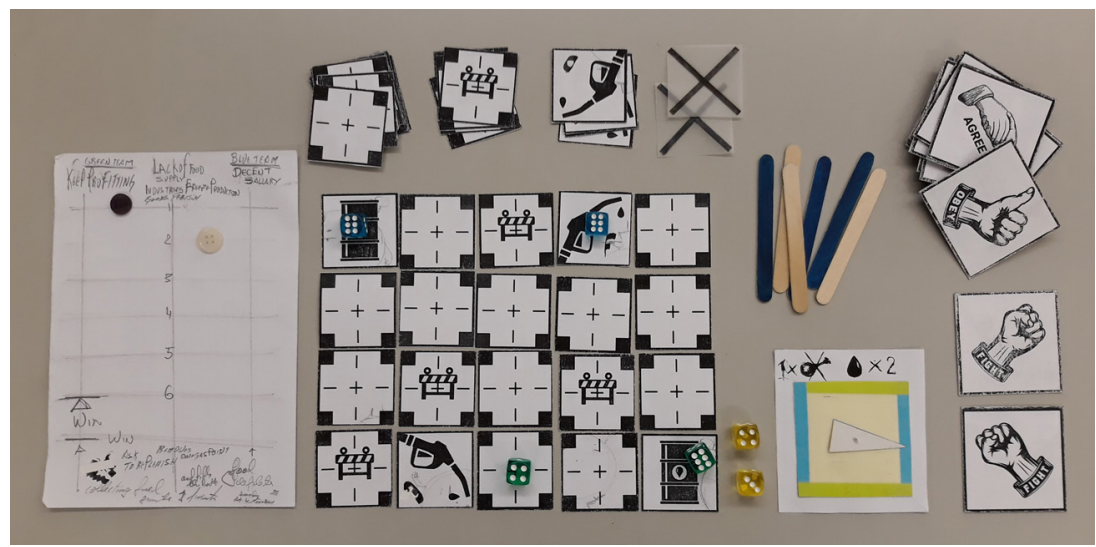

Figure 7. Gas Crisis is a multiplayer game for creating procedural advantages in contrived circumstances.

Gas Crisis is a multiplayer game where two factions struggle to dominate gas distribution. It aims for collaborative Attitudes, as control of the factions is negotiated between two players. Players use mental models (Competencies) to be able to foresee or predict moves that can give them a strategic advantage. The game also uses communal space (Resources), as actions occur in co-location, as well as chance and 
serendipity (Procedures), since actions are taken over a common territory made of obstacles and gas stations, that are drawn at random from a shuffled card deck.

\section{Preliminary Results, Conclusions and Future work}

At the moment, we were able to formulate the following preliminary results:

1. We noticed that combining communal space and collective knowledge in games can reclaim the attention of players upon unnoticed possibilities that were previously seen as unimportant.

2. We witnessed that Procedures may help shape Resources for specific purposes, e.g. open-ended inquiry (Procedures) can help building a pool of collective knowledge (Procedures), which in turn can be helpful for creating new things (Shirky, 2010).

We were also able to draw some limitations:

1. Destructive creativity can call for transformations in such an extent that they risk collapsing the game's gameplay and even lead to irrelevant solutions.

2. Peer talking can easily turn into a monologue by a skilful player that takes charge of other players' actions.

We have identified some conclusions regarding this framework:

1. The framework's key-aspects relate in rather complex fashions. This is an opportunity to inspect how they articulate with one another, to find additional aspects and ways to integrate them as game features;

2. By making players assume new Attitudes and Competencies we are able to incite autonomous learning, while overcoming resistance to change and entrenched habits.

We were also able to draw some hypotheses to inspect in future work:

1. We suspect that speculating about how characters might conduct themselves in a game universe, can inspire new possibilities to be creative, which may eventually lead us to a new key-aspect;

2. We found suggestions pointing at new key-aspects, that can become potential Competencies for a creative economy: analysing, for deep understanding of diverse phenomena; integrating, for enabling one to incorporate information, rules, challenges or extra components into a given process; conceptualizing, for one to be able to formulate new hypotheses; and re-creating, for enabling one to develop alternative versions of existing things (Smilan, 2016).

3. We found suggestions that being committed or applying oneself to tasks at hand can be useful for cultivating creative literacy, as according to Ribeiro (2008), this is about re-orienting one's internal disposition to focus specific objectives.

4. We have found that emergence is about making countless combinations of rules and mechanics of systems for bringing something to existence. This can be useful to demonstrate the potential of games for cultivating creative literacy, as according to 
Bogost (2006, p. 121), by privileging emergence over progression we will "maximize the expressive affordances of the game medium".

\section{Acknowledgements}

The research leading to these results was supported by the FCT, reference SFRH/BD/137169/2018, financed by the Human Capital Operational Programme (HCOP), under the European Social Fund and national funds of the MCTES.

\section{References}

Bauman, Z. (2006). Liquid modernity (7th ed.). Malden, USA: Polity Press.

Bogost, I. (2006). Unit operations: An approach to videogame criticism. Cambridge, Massachusetts: MIT Press.

Bryant, C. (2010). A 21st-century art room: The remix of creativity and technology. In Art education, 63(2), 43-48. doi:10.1080/00043125.2010.11519061

Brown, T. \& Wyatt, J. (2010). Design thinking for social innovation. In Stanford social innovation review, (Winter 2010), 30-35. doi:10.1596/1020-797X_12_1_29

Carvalhais, M. \& Cardoso, P. (2010). Empathy in the ergodic experience of computational aesthetics. In ISEA 2018: International symposium on electronic art, 220-226. Durban, South Africa.

Clifton, N., Crick, T. \& Fuzi, A. (2012). New economic models for, and from, co-working. Wales: Cardiff Metropolitan University.

Cross, N. (2008). Engineering design methods: Strategies for product design (4th ed.). Chichester: John Wiley \& Sons Ltd.

De Bono, E. (1994). Parallel thinking: From socratic thinking to de Bono thinking. London, UK: VIKING, Penguin Group, Inc.

Eagleman, D. (2011). Incognito: The secret lives of the brain. New York: Pantheon Books.

Flanagan, M. (2009). Critical play: Radical game design. London: The MIT Press.

Fronteiras do Pensamento e Instituto CPFL (2013, December 5). António Damásio - exclusive interview (Mário M. Interviewer) [YouTube video]. Accessed July 8, 2019, from: http://www.institutocpfl. org.br/2013/12/05/fronteiras-do-pensamento-e-instituto-cpfl-cultura-entrevista-exclusiva-comantonio-damasio/

Gee, J. P. (2004). Situated language and learning: A critique of traditional schooling. New York: Routledge. https://doi.org/10.1111/j.1467-9345.2006.02802_1.x

Geary, J. (2011). I is an other: The secret life of metaphor and how it shapes the way we see the world (1st ed.). New York: HarperCollins.

Hunter, M. (2012). Creative intelligence and its application to entrepreneurial opportunity and ethics. In Contemporary readings in law and social justice, 4(1), 69-149. doi: 10.3366/ajicl.2011.0005 
Melo, R. M. C. de. (2018). On Serendipity in the digital medium: Towards a framework for valuable unpredictability in interaction design (PhD diss., Universidade do Porto). Retrieved June11, 2019 from: https://repositorio-aberto.up.pt/bitstream/10216/113140/2/274022.pdf

Pun, S., \& Nanyang Technological University. (2009). Creative thinking through visual literacy. In Business education \& accreditation, 1(1), 1-39. Hilo: The Institute for Business and Finance Research, LLC.

Ribeiro, A. (2018). O mistério da criatividade: teorias e práticas criativas nas ciências, na vida quotidiana e na educação. Porto: Edições Afrontamento, Lda.

Schell, J. (2008). The art of game design: A book of lenses (2nd ed.). Burlington: Elsevier Inc.

Shirky, C. (2010). Cognitive surplus: Creativity and generosity in a connected age: How technology makes consumers into collaborators. London, UK: Penguin Books Ltd.

Sicart, M. (2014). Play matters. Cambridge, UK: the MIT Press.

Smilan, C. (2016). Developing visual creative literacies through integrating art-based inquiry. In The clearing house: A journal of educational strategies, issues and ideas, 89(4-5), 167-178. doi:10.108 0/00098655.2016.1170463

Vygotsky, L. S. (2004). Imagination and creativity in childhood. In Journal of russian and east european psychology, 42(1), 7-97. doi: 10.2753/RPO1061-0405290173

Woods, P. (2007). Creative literacy. In Craft, A., Jeffrey, B., \& Leibling, M. (Eds.), Creativity in education (3rd ed.) (pp. 62-79). New York: Continuum.

José Raimundo

INESC TEC / Faculdade de Engenharia da Universidade do Porto

Email: up201307174@fe.up.pt

ORCID: |http://orcid.org/0000-0002-9686-1336

Pedro Cardoso

Faculdades de Engenharia e de Belas Artes da Universidade do Porto

Email: pcardoso@fba.up.pt

ORCID: |http://orcid.org/0000-0001-8546-4194

Miguel Carvalhais

INESC TEC / Faculdade de Belas Artes da Universidade do Porto

Email: mcarvalhais@fba.up.pt ORCID:|http://orcid.org/0000-0002-4880-2542

António Coelho

INESC TEC / Faculdade de Engenharia da Universidade do Porto

Email: acoelho@fe.up.pt ORCID:http://orcid.org/0000-0001-7949-2877 


\section{Correspondência}

José Raimundo

Campus da Faculdade de Engenharia da Universidade do Porto

Rua Dr. Roberto Frias

4200-465 Porto

Portugal

Data de submissão: Julho 2019

Data de avaliação: Setembro 2019

Data de publicação: Dezembro 2020 